\title{
UMOWY PRAWA CYWILNEGO JAKO PODSTAWA ZATRUDNIENIA - WYBRANE ZAGADNIENIA
}

\begin{abstract}
Streszczenie. Przedmiotem niniejszego opracowania jest kwestia wykorzystywania umów prawa cywilnego jako podstawy świadczenia pracy. Ze względu na istniejące w obowiązującym ustawodawstwie różnice w prawnym unormowaniu zatrudnienia pracowniczego i niepracowniczego stosowanie umów cywilnych w stosunkach zatrudnienia pociąga za sobą doniosłe skutki społeczne. Równocześnie kwestia ta pozostaje niezwykle aktualna ze względu na utrzymującą się skalę zjawiska zawierania umów cywilnoprawnych w miejsce tradycyjnie zawieranych umów o pracę. $\mathrm{Z}$ uwagi na ograniczone ramy opracowania podjęte rozważania koncentrują się na wybranych aspektach zatrudnienia na podstawie umów prawa cywilnego.
\end{abstract}

Słowa kluczowe: zatrudnienie, umowy prawa cywilnego, prawo pracy, elastyczność, stosunek pracy.

1.

Zjawisko globalizacji gospodarki światowej i związany z tym wzrost konkurencyjności wpływają na rynek pracy i model zatrudnienia pracowników (Walczak 2011, 81-82). Cechą gospodarki postindustrialnej jest elastyczność, która w dziedzinie zatrudnienia oznacza zdolność dostosowania struktury, wielkości i kwalifikacji pracowników do zmieniających się potrzeb pracodawcy (Patulski 2008, 64). J. Atkinson wyróżnił cztery typy elastyczności w kształtowaniu zatrudnienia na poziomie przedsiębiorstwa. Są to: elastyczność ilościowa (numeryczna) rozumiana jako zdolność dostosowania wielkości zatrudnienia do zmian w zakresie wielkości popytu; jej odmianą jest elastyczność czasu pracy, która przejawia się w możliwości dostosowania długości i organizacji czasu pracy do potrzeb przedsiębiorstwa, pracownika bądź grupy pracowników; elastyczność zadaniowa (funkcjonalna), która oznacza zdolność firmy do zmiany realizowanych zadań bez konieczności korzystania z zasobów zewnętrznego rynku pracy, osiągana dzięki wewnętrznej mobilności pracowników oraz elastyczność płac, która wyraża się w możliwości dostosowania wysokości i struktury wynagrodzeń do sytuacji ekonomicznej przedsiębiorstwa (Atkinson 1984, 28-81). Konieczność sprostania wymaganiom kreowanym przez zmieniającą się rzeczywistość skutkuje wzrostem

* Uniwersytet Rzeszowski, Wydział Prawa i Administracji, Zakład Prawa Pracy i Ubezpieczeń Społecznych, aruszel@ur.edu.pl 
znaczenia atypowych (nietypowych) pracowniczych i niepracowniczych form zatrudnienia, które w mniejszym lub większym stopniu odbiegają od „typowego” modelu zatrudnienia pracowników na podstawie umowy o pracę na czas nieokreślony, w pełnym wymiarze czasu pracy, świadczonej w siedzibie pracodawcy, w określonych ramach czasowych. Wśród atypowych niepracowniczych form zatrudnienia polski rynek pracy charakteryzuje szerokie wykorzystywanie umów prawa cywilnego - umowy o dzieło, umowy zlecenia oraz innych umów o świadczenie usług. W przeważającej liczbie przypadków świadczenie pracy na tej podstawie odbywa się w ramach samozatrudnienia, czyli jednoosobowej działalności gospodarczej osoby zatrudnionej, prowadzonej na jej własny rachunek i ryzyko (Ludera-Ruszel 2017, 45).

\section{2.}

Sąd Najwyższy w wyroku z dnia 9 grudnia 1999 r. (I PKN 432/99, OSNP 2001, nr 9, poz. 310) wskazał, że zatrudnienie nie musi mieć charakteru pracowniczego, a praca może być świadczona także na podstawie umów cywilnoprawnych. Pogląd ten pozostaje aktualny w odniesieniu do jednej umowy stron, jako podstawy świadczenia pracy określonego rodzaju, jak również kolejnych umów zawieranych przez strony, obok istniejącej już umowy o pracę bądź umowy cywilnoprawnej. W wyroku z dnia 13 marca 1997 r. (I PKN 43/97, OSNP 1997, nr 24, poz. 494) Sąd Najwyższy potwierdził dopuszczalność zawierania odrębnych umów o pracę między tymi samymi stronami pod warunkiem, że ich przedmiotem jest praca innego rodzaju, niż wynikająca z zawartej wcześniej umowy o pracę. Dotyczy to odpowiednio także umowy cywilnoprawnej zawartej przez pracodawcę i pracownika na wykonywanie dodatkowych zadań, obok objętych treścią stosunku pracy (por. wyrok SN z 30.06.2000 r., II UKN 523/99, OSNP 2002, nr 1, poz. 22). $\mathrm{Z}$ powyższego wynika, że w stosunkach zatrudnienia nie obowiązuje prymat zatrudnienia pracowniczego nad zatrudnieniem niepracowniczym. Równocześnie brakuje domniemania prawnego zawarcia umowy o pracę, w szczególności takie domniemanie nie wynika z dyspozycji art. 22 § $1^{1}$ k.p. (Goździewicz 2015, 51; Rączka 1997, 11; zob. wyrok SN z 9.12.1999 r., I PKN 432/99, OSNAPiUS 2001/9/310) $)^{1}$.

Zgodnie z cywilistyczną zasadą swobody umów, co do zasady, wybór podstawy prawnej zatrudnienia pozostaje $\mathrm{w}$ gestii zainteresowanych stron (art. $353^{1}$ k.c. w zw. $\mathrm{z}$ art. $300 \mathrm{k}$.p. $)^{2}$. Zgodny zamiar stron - wyrażony w nazwie umowy - oraz cel umowy, jako szczególne reguły wykładni oświadczeń woli, wskazane w art. 65

${ }^{1}$ Odmiennie Grzegorz Orłowski, „Umowa zlecenia a miękkie domniemanie stosunku pracy”, Monitor Prawa Pracy 2007, nr 3, s. 135.

${ }^{2}$ Stanowisko to potwierdza bogate orzecznictwo Sądu Najwyższego. Przykładowo w wyroku z dnia 26 marca 2008 r. (I UK 282/07, LEX nr 411051) Sąd Najwyższy orzekł, że „O rodzaju 
$\S 2$ k.c. w zw. z art. 300 k.p., mogą przesądzać o rodzaju zawartej umowy. Dotyczy to zwłaszcza przypadku, gdy zawarta przez strony umowa wykazuje cechy wspólne dla umowy o pracę i umowy prawa cywilnego z jednakowym ich nasileniem (zob. wyrok SN z 10.06.1998 r., I PKN 191/98, OSNP 1999, nr 10, poz. 184; wyrok SN z 28.10 .1998 r., I PKN 404/98, OSNP 1998, nr 24, poz. 774; wyrok SN z 27.05.2010 r., II PK 354/09, Lex nr 598002)3. Nie w każdym jednak przypadku zgodny zamiar stron - uzewnętrzniony w nazwie umowy - będzie przesądzał o dojściu do skutku umowy cywilnoprawnej jako podstawy zatrudnienia. Ponadto, ze względu na zależność, w jakiej znajduje się pracownik od podmiotu zatrudniającego, ustalenie, czy w konkretnym przypadku wola zawarcia umowy prawa cywilnego została swobodnie wyrażona, może w praktyce okazać się znacznie utrudnione, a nawet niemożliwe. Na gruncie stosunku pracy cywilna zasada swobody umów doznaje ograniczeń (Świątkowski 2015, 245). Znaczenie normy wynikającej z art. $22 \S 1^{1}$ k.p. wyraża się w tym, że wypływa z niej nakaz dokonywania oceny, czy istniejący między stronami stosunek prawny odznacza się cechami właściwymi dla stosunku pracy. W sytuacji, gdy zawarta przez strony umowa zawiera wszystkie cechy stosunku pracy, nie jest możliwe zastąpienie stosunku pracy umową prawa cywilnego, co potwierdza treść art. $22 \S 1^{2}$ k.p. Wyraża się w tym ochronny charakter norm prawa pracy, które mają na celu ochronę pracownika, jako z założenia słabszą stronę stosunku pracy, przykładowo przed wykonywaniem przez niego pracy ponad ustalone limity czasu pracy. Jak wskazał Sąd Najwyższy, oceny charakteru umowy należy dokonywać nie tylko na podstawie przyjętych przez jej strony postanowień, które mogą mieć na celu stworzenie pozoru innej umowy, lecz także na podstawie faktycznych warunków jej wykonywania (zob. wyrok SN z 5.05.2010 r., I PKN 8/10, Lex nr 602668), w szczególności będzie to świadczenie pracy w określonej zależności od podmiotu zatrudniającego, właściwej dla stosunku pracy (zob. wyrok SN z 11.09.2013 r., II PK 372/12, OSNP 2014, nr 6, poz. 80). Zatrudnienie na podstawie umowy cywilnoprawnej $\mathrm{w}$ warunkach właściwych dla stosunku pracy, jak również zawarcie przez pracodawcę i pracownika umowy prawa cywilnego przy pracach tego samego rodzaju, co objęte stosunkiem pracy, nie skutkuje jej nieważnością, jako pozornej czynności prawnej (w pierwszym przypadku) lub czynności mającej na celu obejście ochronnych regulacji prawa pracy (w drugim przypadku). W tym zakresie Kodeks pracy, we wspomnianym wyżej art. $22 \S 1^{1}$ k.p., przewiduje inny skutek, tj. nawiązanie na tej podstawie stosunku pracy. Skutek ten jest niezależny od tego, czy w konkretnym przypadku zawarcie umowy cywilnoprawnej odpowiadało interesowi stron.

zawartej umowy decyduje nie tylko i nie tyle jej nazwa, ile cel i zgodny zamiar stron. O wyborze podstawy zatrudnienia decyduje bowiem przede wszystkim zgodna, autonomiczna wola stron".

${ }^{3} \mathrm{~W}$ wyroku z dnia 23 stycznia 2002 r. Sąd Najwyższy wskazał, że umowa nie może mieć charakteru mieszanego - umowy o pracę i umowy prawa cywilnego (I PKN 786/00, OSNP 2004, nr 2, poz. 30). 
3.

Stosowanie umów prawa cywilnego w stosunkach zatrudnienia jest jednym ze sposobów na osiągnięcie elastyczności numerycznej, funkcjonalnej oraz elastyczności płac. Umowy prawa cywilnego nie podlegają przepisom Kodeksu pracy oraz ustawy określającej minimalne wynagrodzenie za pracę (Ustawa z dnia 10 października 2002 r. o minimalnym wynagrodzeniu za pracę, t.j. Dz.U. z 2017 r., poz. 847). Z tego względu umożliwiają łatwą i pozbawioną kosztów zmianę poziomu, struktury i warunków zatrudniania bez ograniczeń wynikających z ochronnych przepisów prawa pracy i zasady uprzywilejowania pracowników, w tym ustalenie wynagrodzenia na poziomie znacznie odbiegającym od minimalnego wynagrodzenia za pracę (Godlewska-Bujok 2014, 5). Z tego powodu w obecnych warunkach rynkowych umowy prawa cywilnego są powszechnie stosowane zamiast umowy o pracę. Polityka zatrudnienia, w której zatrudnienie cywilnoprawne jest postrzegane jako alternatywa dla zatrudnienia na podstawie umowy o pracę, prowadzi do sytuacji, w której umowy te są nadużywane przez pracodawców i stosowane niezgodnie z ich społeczno-gospodarczym przeznaczeniem, często wbrew woli zatrudnionych. Dotyczy to zwłaszcza umów cywilnoprawnych zawieranych w warunkach tzw. samozatrudnienia ekonomicznie zależnego, gdzie świadczenie pracy odbywa się wyłącznie bądź w przeważającym zakresie na rzecz jednego podmiotu w sposób zbliżony do stosunku pracy (Ludera-Ruszel 2017, 45-46). Problem „niechcianego” zatrudnienia cywilnoprawnego dotyczy tych zatrudnionych, którzy mają słabą pozycję negocjacyjną względem pracodawcy. Jest to związane z brakiem bądź niskim poziomem ochrony związkowej takich zatrudnionych lub ich niekorzystną sytuacją na rynku pracy, determinowaną przez ich wiek, obowiązki rodzinne oraz brak kwalifikacji zawodowych bądź nieposiadanie kwalifikacji dostosowanych do aktualnych potrzeb rynku pracy. W stosunku do takich osób umowa prawa cywilnego nabiera cech umowy adhezyjnej (umowy o przystąpienie), gdzie rodzaj umowy oraz warunki zatrudnienia określa jednostronnie silniejszy ekonomicznie podmiot zatrudniający, bez ich negocjowania z zatrudnianym, który może jedynie przystąpić do takiej umowy bądź zrezygnować z jej zawarcia.

Nadużycia w zakresie stosowania umów prawa cywilnego odpowiadają za istniejący stan głębokiej segmentacji polskiego rynku pracy na tzw. lepszych i gorszych pracowników, których stosunek zatrudnienia charakteryzuje niepewność, niestabilność i brak poczucia bezpieczeństwa (Patulski 2013, 81-82). Ze względu na brak pewności i stabilności, które charakteryzują „niechciane” zatrudnienie cywilnoprawne, jest ono powszechnie utożsamiane z prekariatem - pojęciem stosowanym na oznaczenie kategorii osób pozbawionych siedmiu gwarancji zatrudnienia oznaczonych przez G. Standinga jako: gwarancja rynku pracy (labour market security), gwarancja zatrudnienia (employment security), 
gwarancja pracy (job security), gwarancja bezpieczeństwa w pracy (work security), gwarancja reprodukcji umiejętności (sill reproduction security), gwarancja dochodu (income security) oraz gwarancja reprezentacji (representation security) (Standing 2011, 18, 27).

\section{4.}

Konstytucyjna zasada ochrony pracy (art. 24 Konstytucji RP) rozciąga się na każdy przypadek świadczenia pracy, bez względu na jej podstawę prawną, a zatem nie tylko na podstawie stosunku pracy, ale także w oparciu o umowy prawa cywilnego (zob. wyrok SN z 7.10.2004 r., II PK 29/04, OSNP 2005, nr 7, poz. 97). Zasada ta stanowi jedną z podstawowych zasad, na jakich opiera się model ustroju społeczno-gospodarczego państwa, który został określony w art. 20 Konstytucji RP jako społeczna gospodarka rynkowa (Dral, Bury 2014, 236). Z zasady tej wynika dla władzy państwowej nakaz ochrony pracy oraz upoważnienie do sprawowania nadzoru nad warunkami pracy. Objęcie pracy ochroną konstytucyjną oznacza, że stosunki mające za przedmiot świadczenie pracy nie są pozostawione swobodnemu działaniu mechanizmów rynkowych. Konflikt, jaki występuje na linii praca-kapitał, generuje rozmaite, coraz to nowsze, zagrożenia dla „ludzi pracy", które wymagają ingerencji państwa w relację między zatrudnionym a zatrudniającym w celu zagwarantowania równowagi między stronami w stosunku zatrudnienia. W tym sensie zasada ochrony pracy wyznacza dla podmiotu zatrudniającego granice korzystania w stosunkach zatrudnienia ze swobody działalności gospodarczej (Oniszczuk 2010, 297). Nadanie pracy wartości konstytucyjnej wynika ze szczególnego znaczenia pracy w wymiarze społecznym i indywidualnym. Praca, jako przedmiot „transakcji” w stosunku zatrudnienia, nie jest towarem $^{4}$, nie da się jej bowiem oddzielić od osoby pracownika. W rzeczywistości ochroną na gruncie tej zasady objęty jest człowiek świadczący pracę, co oznacza, że realizacja zasady ochrony pracy ma istotne znaczenie dla zagwarantowania ochrony godności osoby zatrudnionej, której poszanowanie ma swoją podstawę w art. 30 Konstytucji RP (Liszcz 2014, 254).

Przejawem obowiązywania zasady ochrony pracy są istniejące rozwiązania prawne i instytucjonalne - posiadające częściowo konstytucyjną podstawę - które mają na celu zniwelować negatywne dla zatrudnionych skutki, jakie potencjalnie mogą wynikać ze świadczenia pracy. Z zasady tej wynika obowiązek państwa zagwarantowania prawa wyboru i wykonywania zawodu oraz wyboru miejsca wykonywania pracy, zakaz stałego zatrudniania dzieci do lat 16, określenie wysokości minimalnego wynagrodzenia za pracę, zagwarantowanie zatrudnionym

${ }^{4}$ Jest to podstawowa zasada, na której swoją działalność opiera Międzynarodowa Organizacja Pracy (MOP), a wyrażona została ona w Deklaracji filadelfijskiej z dnia 10 kwietnia 1944 r. 
możliwości zrzeszania się w związkach zawodowych w celu ochrony swoich praw, prowadzenie polityki zmierzającej do pełnego, produktywnego zatrudnienia, zagwarantowanie prawa do bezpiecznych i higienicznych warunków świadczenia pracy oraz prawa do ustawowo określonych dni wolnych od pracy oraz corocznych płatnych urlopów, jak również ustalenie minimalnych norm czasu pracy (Skrzydło 2013).

\section{5.}

Na gruncie obowiązującego ustawodawstwa najszerszy zakres ochrony stosunku zatrudnienia przysługuje osobom świadczącym pracę na podstawie stosunku pracy. Ochrona pracownika stanowi cel prawa pracy i jego funkcji ochronnej. Przejawem ochronnej funkcji prawa pracy jest wspomniana wyżej zasada uprzywilejowania pracownika (art. 18 k.p.), określana też jako zasada ochrony uprawnień pracowniczych (Rączka 2010, 73), która ogranicza swobodę kontraktową stron stosunku pracy w odniesieniu do postanowień, które są mniej korzystne dla pracownika, niż wynikające z przepisów prawa pracy. Wiąże się $\mathrm{z}$ tym charakter norm prawa pracy, które w przeważającym zakresie stanowią normy jednostronnie bezwzględnie obowiązujące (semiimperatywne). Umowy prawa cywilnego nie gwarantują zatrudnionym analogicznego do umowy o pracę poziomu ochrony i stabilizacji stosunku zatrudnienia. Wyjątek dotyczy jedynie umowy o pracę nakładczą, do której stosuje się przepisy prawa pracy w zakresie określonym w rozporządzeniu Rady Ministrów (art. 303 § 1 k.p.) (Rozporządzenie Rady Ministrów z dnia 31 grudnia 1975 r. w sprawie uprawnień pracowniczych osób wykonujących pracę nakładczą, Dz.U. z 1976 r., nr 3, poz. 19). Strony umowy prawa cywilnego korzystają z szerokiej swobody kształtowania wzajemnych praw i obowiązków, która podlega tylko ogólnym ograniczeniom wynikającym z zasady swobody umów, wskazanych w art. $353^{1}$ k.c. Oznacza to możliwość kształtowania postanowień umownych w sposób odbiegający na niekorzyść zatrudnionego od regulacji ustawowych.

Zasada ochrony pracy dopuszcza zróżnicowanie poziomu ochrony zatrudnionych ze względu na różnice $w$ ich położeniu względem podmiotu zatrudniającego. Dyferencjacja poziomu ochrony pracy różnych kategorii zatrudnionych nie stanowi naruszenia zasady równości wobec prawa (art. 32 ust. 1 Konstytucji RP), jeżeli nie prowadzi do odmiennego traktowania podmiotów charakteryzujących się w równym stopniu daną cechą istotną (relewantną) (zob. wyrok TK z 12.12.1994 r., K 3/94, OTK 1994, nr 2, poz. 42). Istniejące zróżnicowanie sytuacji prawnej zatrudnionych w pracowniczych i niepracowniczych formach zatrudnienia uzasadnia się specyfiką pracy w ramach stosunku pracy, która świadczona jest w warunkach organizacyjnego podporządkowania pracownika pracodawcy (Ludera-Ruszel 2017, 50-53). W ramach stosunku podporządkowania pracodawca może wpływać 
na proces świadczenia pracy przez wydawanie pracownikowi wiążących poleceń dotyczących pracy (Ludera-Ruszel 2017, 50-53). Pracownicze podporządkowanie stanowi cechę konieczną stosunku pracy, wyróżniającą go od innych form zatrudnienia, w szczególności tych opartych na umowach prawa cywilnego (Duraj 2013a, 290), gdzie cechy kierownictwa i podporządkowania nie występują z takim nasileniem jak w stosunku pracy (zob. wyrok SN z 11.09.2013 r., II PK 372/12, OSNP 2014/6/80).

Element podporządkowania osłabia pozycję pracownika w stosunku pracy, jednak o jego faktycznej pozycji względem pracodawcy decyduje element zależności ekonomicznej (Duraj 2013b, 8-14). Pod pojęciem zależności ekonomicznej rozumie się sytuację, w której ,dochody wykonawcy pracy zależą prawie wyłącznie (w przeważającej części) od podmiotu zatrudniającego, który osiąga korzyści z pracy wykonywanej przez tę osobę" (Duraj 2011, 54). Zależności ekonomicznej nie należy utożsamiać z pracowniczym podporządkowaniem, jednak poziom uzależnienia ekonomicznego pracownika od pracodawcy - determinowany przez jego sytuację na rynku pracy - wpływa bezpośrednio na stopień pracowniczego podporządkowania (Liszcz 2011, 116-117). Zależność ekonomiczna jest cechą swoistą nie tylko dla stosunku pracy, ale występuje - często z takim samym nasileniem - także w zatrudnieniu opartym na umowach prawa cywilnego, co zbliża stosunek cywilnoprawny do stosunku pracy. Stosunek zależności ekonomicznej występuje zwłaszcza w tzw. samozatrudnieniu ekonomicznie zależnym, w którym świadczenie pracy odbywa się wyłącznie bądź w przeważającym zakresie na rzecz jednego podmiotu, co odróżnia tę kategorię prawną od „klasycznego" samozatrudnienia.

Z przeprowadzonych rozważań wynika, że umowy prawa cywilnego stanowią specyfikę polskiego rynku pracy. Pomimo że zatrudnienie cywilnoprawne stanowi prawnie dopuszczalną formę zatrudnienia, wykorzystywanie umów prawa cywilnego w stosunkach zatrudnienia jest generalnie odbierane jako zjawisko negatywne. Zatrudnienie cywilnoprawne jest powszechnie utożsamiane z brakiem pewności i bezpieczeństwa, które dla odmiany charakteryzują zatrudnienie na podstawie stosunku pracy. Zależność ekonomiczna pracownika od pracodawcy właściwa dla stosunku pracy występuje także w zatrudnieniu cywilnoprawnym, w takim samym, a często nawet większym stopniu niż w stosunku pracy. Dotyczy to zwłaszcza kategorii określanej jako samozatrudnienie ekonomicznie zależne. Ze względu na ów stan zależności ekonomicznej, jaki charakteryzuje tę grupę osób świadczących pracę na podstawie umów prawa cywilnego, sytuacja takich zatrudnionych jest zbliżona do sytuacji pracownika w stosunku pracy. W takich uwarunkowaniach postulować należy przyznanie osobom zatrudnionym na podstawie umów prawa cywilnego szerszego niż obecnie zakresu ochrony stosunku zatrudnienia. 


\section{BIBLIOGRAFIA}

Atkinson, John. 1984. „Manpower strategies for flexible organizations”. Personal Management 8: $28-81$.

Dral, Antoni, Beata Bury. 2014. „Zasada ochrony pracy w świetle Konstytucji RP”. Przeglad Prawa Konstytucyjnego 3: 233-251.

Duraj, Tomasz. 2011. „Tradycyjne ujęcie pracowniczego podporządkowania - wybrane problemy prawne". Studia Prawno-Ekonomiczne LXXXIII: 35-61.

Duraj, Tomasz. 2013a. „Pracownicze podporządkowanie a pozycja stron stosunku pracy i jego charakter prawny”. W Prawo pracy. Refleksje i poszukiwania. Ksiega Jubileuszowa Profesora Jerzego Wratnego. Red. Gertruda Uścińska. 290-302. Warszawa: Instytut Pracy i Spraw Socjalnych.

Duraj, Tomasz. 2013b, „Zależność ekonomiczna jako kryterium identyfikacji stosunku pracy - analiza krytyczna". Praca i Zabezpieczenie Społeczne 6: 8-14.

Godlewska-Bujok, Barbara. 2014. „Prekariat a umowy prekaryjne. Głos w dyskusji”. Praca i Zabezpieczenie Społeczne 9: 2-6.

Goździewicz, Grzegorz. 2015. „Komentarz”. W Kodeks pracy. Red. Ludwik Florek. 183-218. Warszawa: Wolters Kluwer.

Liszcz, Teresa. 2011. „W sprawie podporządkowania pracownika”. W Wspótczesne problemy prawa pracy i ubezpieczeń społecznych. Red. Ludwik Florek, Łukasz Pisarczyk. 114-122. Warszawa: LexisNexis.

Liszcz, Teresa. 2014. „Praca i kapitał w Konstytucji Rzeczypospolitej Polskiej”. Studia Iuridica Lublinensia 22: 253-278.

Ludera-Ruszel, Agata. 2017. „Samozatrudnienie ekonomicznie zależne a konstytucyjna zasada ochrony pracy". Roczniki Nauk Prawnych XXVII, 1: 43-61.

Oniszczuk, Jerzy. 2010. „Źródła prawa pracy”. W Zarys systemu prawa pracy. Tom I. Czesść ogólna. Red. Krzysztof W. Baran. 253-466. Warszawa: Wolters Kluwer.

Patulski, Andrzej. 2008. „Nietypowe formy zatrudnienia. Elastyczność czy stabilizacja? Część 1”. Monitor Prawa Pracy 2: 64-68.

Patulski, Andrzej. 2013. „Praca niepewna jako produkt zmian na współczesnym rynku pracy”. W Prawo pracy. Refleksje i poszukiwania. Księga Jubileuszowa Profesora Jerzego Wratnego. Red. Gertruda Uścińska. Warszawa: Instytut Pracy i Spraw Socjalnych.

Rączka, Krzysztof. 1997. „Czy domniemanie stosunku pracy”. Przegląd Ubezpieczeń Społecznych $i$ Gospodarczych 2: 6-11.

Rączka, Krzysztof. 2010. „Komentarz”. W Kodeks pracy. Red. Małgorzata Gersdorf, Krzysztof Rączka, Michał Raczkowski. Warszawa: Wolters Kluwer.

Skrzydło, Wiesław. 2012. Konstytucja RP. Komentarz. Warszawa: Wolters Kluwer.

Standing, Guy. 2011. The Precariat: The New Dangerous Class. London: Bloomsbury.

Świątkowski, Andrzej Marian. 2015a. „Cywilnoprawne zatrudnienie niepracownicze”. W System prawa pracy. Zatrudnienie niepracownicze. Tom VII. Red. Krzysztof W. Baran. Warszawa: Wolters Kluwer.

Świątkowski, Andrzej Marian. 2015b. „Prawo wyboru podstawy zatrudnienia. W Studia Iuridica Lublinensia XXIV(3). Ksiega Jubileuszowa dedykowana Profesor Teresie Liszcz. Lublin: Wydział Prawa i Administracji Uniwersytetu Marii Curie-Skłodowskiej.

Walczak, Krzysztof. 2011. „Wpływ globalizacji i ogólnoświatowego kryzysu na podstawy i warunki zatrudnienia. Wyzwania dla polskiego prawa pracy". W Współczesne problemy prawa pracy i ubezpieczeń społecznych. Red. Ludwik Florek, Łukasz Pisarczyk. Warszawa: LexisNexis. 
Agata Ludera-Ruszel

\title{
EMPLOYMENT UNDER CIVIL LAW CONTRACTS - SELECTED ISSUES
}

\begin{abstract}
This paper offers an analysis of the selected issues of employment under civil law contracts. Due to the differences existing in the national legislation between employee and nonemployee employment the use of civil law contract as a basis for employment has major social implications. At the same time, this issue remains extremely up-to-date due to the persistent scale of civil law contracting in place of traditionally concluded contracts of employment.
\end{abstract}

Keywords: employment, civil law contracts, labour law, flexibility, employment relationship. 